\title{
Hedonism in George Saunder's The Semplica-Girl Diaries.
}

Karunsagar Kanda

PhD. Scholar, Department of English

A.U. College of Arts and Commerce

Andhra University

Visakhapatnam, Andhra Pradesh, India

vennelamasam@gmail.com

Dr. P. Rajendra Karmarkar

Principal

A.U. College of Arts and Commerce

Department of English, Andhra University

Visakhapatnam, Andhra Pradesh, India

Abstract

George Saunders is an American short story writer. His writings include moral sting and stints of realism. This article is an analysis of one of his famous stories The Semplica-Girl

Diaries. The story is a fine example of hedonism which means favouring pleasure and avoiding pain. This article speculates the idea of hedonism in the characters of this story and brings forth the theme of moral myopia. Hedonistic treadmill was at multiple times was being operated by those characters who try to own pleasure in spite of biting bullets. The other elements like American dream and consumerism have been analysed through the lens of narrator.

Keywords: American Dream, Consumerism, Hedonism, Moral Myopia.

The word hedonism originates from the Greek goddess hēdonēa symbol of pleasure. A new lair of hedonistic philosophy seems to spring forth within the works of Democritus. 
He claims joy is something which is advantageous and sorrow disadvantageous. There are other contributors who have joined shoulders in contributing to hedonistic philosophy which is broadly categorised into psychological and ethical. However, the basic idea which permeates around is pleasure and pain.

Pleasure is $h \bar{e} d o n \bar{e}$ and the opposite is algos which personifies pain. There are many contradictory theories and practices which have risen against hedonism which says that it is baleful. Paradox hedonism is one such hinge which stresses that if one broods on pleasure for a long time they might meet with distaste and displeasure.

Gradually hedonistic thoughts took opposite linear action contrary to base form of hedonism. According to Christian belief pleasure seeking is idolatry in the view of God so Christians have asserted against it. Philosophy of hedonism according to Christians argue that, “. . . Adam and Eve lived pleasurable lives in Eden, but because of their Original Sin, we all must suffer; and therefore, it is blasphemous to seek pleasure at the expense of our responsibility to God" (philosophy). In the aftermath the view of hedonism has been under different continuous transformation. Christian beliefs took a new turn from negativity to positivity with regard to hedonism. They believed it is not something sinful but glorifying God. The idea of Christian hedonism is laid by John Piper who said, "Christian Hedonism is the conviction that God's ultimate goal in the world (his glory) and our deepest desire (to be happy) are one and the same, because God is most glorified in us when we are most satisfied in him." (“ChristianHedonism.")

As years passed on hedonism took shape of consumerism which turned out to be hedonistic consumerism.

Consumerism in economic terms can be defined such as chasing after the desires and leading to the excessive consumption beyond one's affordability. Migone has put in his words saying, "Hedonistic consumerism, the highly wasteful and discriminatory pattern of 
consumption that predominates in current capitalist models, is the latest evolution in the form of modern capitalism" (174). This article however discerns the hedonistic perspective in the characters of The Semplica-Girl Diaries who are imbued with consumerism and how they were off feet from hedonistic treadmill. The narrator is duped on having an exuberant life style which is beyond possibility. However, he fell prey to paradox hedonism which lands him inmisery.

The Semplica-Girl Diaries is written in epistolary format with anonymous narrator recording the events of his life in stream of consciousness technique though the reader sometimes might feel that the narrator is a Semplica Girl. The story leads to dystopia which is apparent as it progresses. The narrator is a middle aged man married to Pam. His daughters Eva and Lilly are opposite poles having different characteristics. The narrator is fond of his daughters and doesn't want them to face struggles so he wrestles with his conscience to keep them satisfied and embarks upon positivity though they lack it. He introspects saying:

“Stood looking up at house, sad. Thought: Why sad? Don't be sad. If sad, will make everyone sad. Went in happy, not mentioning bumper, squirrel/mouse smudge, maggots, then gave Eva extra ice cream, due to I had spoken harshly to her.

Have to do better! Be kinder. Start now. Soon they will be grown and how sad, if only memory of you is testy, stressed guy in bad car (The Semplica-Girl Diaries 112)

The story heightens when the narrator's family visits Leslie Torrini. The Torrinis are wealthy and they exhibit their materialistic grandeur to the viewers. The well off Torrinis leave a spec of jealousy in the eyes of the narrator's family. The narrator records his feelings in his diary, "Do not really like rich people, as they make us poor people feel dopey and inadequate. Not that we are poor. I would say we are middle. We are very, very lucky. I know that. But still, it is not right that rich people make us middle people feel dopey and inadequate" (118). 
Naturally, the narrator and his family are eclipsed with material prosperity of Torrinis, they get totally obsessed with SGs who are arranged in their beautiful yard. SG stands for Semplica-Girls who are from the third world countries. Their brains were strewn with a microline. The comparison is clearly drawn out between Ferber and SGs. Ferber is a dog reared up with much love and affection from the boy Thomas. Regardless of humanity SGs are ill-treated as non-human by hanging them as decorative objects. Ferber and SGs are same and identical in the view of narrator. It is obvious in his saying:

"Pulled up to house. Another silence as we regarded blank, empty yard. That is, mostly crabgrass and no red Oriental bridge w/ ancient hoof prints and no outbuildings and not a single SG, but only Ferber, who

we'd kind of forgotten about, and who, as usual, had circled round and round the tree until nearly strangling to death on his gradually shortening leash and was looking up at us with begging eyes in which desperation was combined with a sort of low-boiling anger (The Semplica-Girl Diaries 118).

The story takes a turn when the narrator plans to throw a party for Lilly's birthday. Eva has a sad look on her face as she feels SGs are sad. He convinces her saying that this something natural with SGs which doesn't harm them. As he tries on meeting both the ends, he wins a lottery. He tells of his fortune to Pam and she is joyous on learning about the sudden fortune. The narrator ponders over the balance sheet and the budget he has to spend on Lilly's birthday. Finally, they execute their plan in throwing the party having SGs in their yard. Lilly makes the guests envious of her party by holding it grandly. Eva being so sensitive to the SGs, lets them go off the yard by removing the microline. The narrator and his family are left devastated as they need to pay a huge debt. Pam tries to obtain help from her father to save them from this sudden grab of poverty but he denies saying:

"Let us now speak of what you intend to do with the requested money. Will you be 
putting it aside for a college fund? You will not. Investing in real estate? No. Given a chance to plant some seeds, you flushed those valuable seeds (dollars) away. And for what? A display some find pretty. Well, I do not find it pretty. Since when are people on display a desirable sight? Do-gooders in our church cite conditions of poverty.

O.K., that is fine. But it appears you will soon have a situation of poverty within your own walls. And physician heal thyself is a motto I have oft remembered when tempted to put my oar in relative to some social cause or another. So am going to say no. You people have walked yourselves into some deep water and must now walk yourselves out, teaching your kids (and selves) a valuable lesson from which, in the long term, you and yours will benefit (160).

Pam's father is Farmer rich who has no debt under his belt. He doesn't like SGs and calls them as "showoffy move" (158). He denies showing status to others completely in contrast with the narrator who runs after status. In the end the narrator introspects himself and possible events that would be done by SGs. 
The whole story takes on the wheel of consumerism and questions the American Dream taking sides with paradox hedonism. Consumerism is an economic term which intends a person to have possession of materialistic abundancy but in later years it divested of its past and took a new shape such as over consumption, loss of moral ethos and barbarism. The narrator is pleased to have a life style to greet his hedonistic pleasure. SGs have been disembodied and are considered as commodities to be displayed in his yard. Consumeristic character is displayed in the face of humanity in which he exhausted his own human identity. Eva his daughter is empathetic towards SGs and their pain. She is the character who questions the sadism towards third world women by drawing the pictures that is 'sad SGs' but the narrator tries to teach her the ways of unscrupulous modern man by looking at pleasure and ignoring the pain which is an example of hedonistic impulse.

"Last night, after party, found Eva sad in her room. Asked why. She said no reason. But in sketch pad: crayon pic of row of sad SGs. Could tell were meant to be sad, due to frowns went down off faces like Fu Manchus and tears were dropping in arcs, flowers springing up where tears hit ground. Note to self: Talk to her, explain that it does not hurt, they are not sad but actually happy, given what their prior conditions were like: they chose, are glad, etc" (The Semplica-Girl Diaries 119).

The other question which Saunders poses is the congruity of the concept American dream which is unrealistic in comparison with past. The famous historian James Truslow who coined the term "American dream" elaborated it saying:

"The American dream that has lured tens of millions of all nations to our shores in the past century has not been a dream of merely material plenty though that has doubtlessly counted heavily. It has been much more than that. It has been a dream of being able to grow to fullest development as man and woman, unhampered by the barriers which has slowly been erected in the older civilizations, unrepressed by social orders which had developed for 
the benefit of classes rather than for the simple human being of any and every class" (29).This American dream which was so promising in the past, remains clueless in the current American society.

The narrator like many other Americans feels disappointed over his status as a middle class and delves in deep thoughts to reach beyond materialistic progress. The ego centric narrator wants his presence to be felt in the society such that he is craving for his own identity. His inferiority lets him down sometimes leaving a mark of suspicion on the American dream. The narrator who ponders over his helplessness says, "Someday, I'm sure, dreams will come true. But when? Why not now? Why not?" (The Semplica-Girl Diaries 129) Coinciding with his wish the impossible becomes possible by winning a "Scratch-Off!" card.

The overjoyed narrator switches back to his belief in American dream saying, "Friday most incredible day ever! Do not need to even write down, as will never forget this awesome day! But will record for future generations. Nice for them to know that good luck and happiness real and possible! In America of my time, want them to know, anything possible!" (129). However, his joy flickers away in the end as the SGs leave his yard. His poor financial status revisits him again. When the narrator says, "why would they do that? They chose to be here"(152) the cop mocks him by replying sarcastically it's "American dream" (152). The narrator was overplayed by his American dream leaving himself in obscurity and indecisiveness to move further. To suffice what is said above Carla Iroldi has put the American dream in his own words:

“The Semplica Girls' low social standing in Saunders' dystopia, which places them at a much higher disadvantage in their quest for the American Dream, forces to us to realize how limiting our notion of success is in the sense that the term is not applicable to the less fortunate in our society. To further understand this concept, it is crucial to note just how low 
the Semplica Girls are in the social hierarchy. We get a sense of their worth simply through the fact that all these girls as a whole better fit the definition of a symbol in the story rather than individual characters"( www.montclair.edu)

The first impulse of hedonistic idea is plausible in the narrator who does a way with pain in seeking the pleasure. The narrator drives his intuitions in having a wealthy life but fumbles in acquiring it. He desires after a promising life and becomes wealth conscious and does not know how to be satisfied with limited means. This is obvious in his stream of consciousness, "When will I have sufficient leisure/wealth to sit on hay-bale watching moon rise, while in luxurious mansion family sleeps? At that time, will have chance to reflect deeply on meaning of life etc., etc. Have a feeling and have always had a feeling that this and other good things will happen for us!” (The Semplica-Girl Diaries 112).

Man by nature is a breed of grave greediness as he never settles himself for anything less. The ultimate end of every person is desire. If desire is hollow a man is nothing in his self. A new end erupts when the old end is fulfilled. Though the ends are satiated happiness doesn't get obtained hence it is named as hedonistic adaptation or hedonistic treadmill. Jean Jacques Rousseau has rightly defined hedonistic treadmill saying, "Since these conveniences by becoming habitual had almost entirely ceased to be enjoyable, and at the same time degenerated into true needs, it became much crueller to be deprived of them than to possess them was sweet, and men were unhappy to lose them without being happy to possess them." It is so apt to the narrator of The Semplica-Girl Dairies who wins a lottery yet he doesn't get on with what he has but he alters his wishes trying to make more ends wishing for more pleasure. Even his wife stands by his side accepting his decision take a run on treadmill. After winning lottery the initial thought that flares up is to clear their credit card dues but Pam and narrator think otherwise by scheming a financial plan for throwing party for Lilly's birthday. They scheme: 
"So we hatched up scheme, then did. Which was: went to Greenway Landscaping, had them do total new yard design, incl. ten rose bushes + cedar pathway + pond + small hottub + four-SG arrangement! Big fun part was, how soon could it be done? Plus could it be done secret? Greenway said, for price, could doin one day, while kids at school. (Note to self: write letter praising Melanie, Greenway gal: super facilitator.)”(130-131)

It is a fine example of false belief in social status. They are obsessed with the wrong notion that wealth promises happiness. The harbinger of happiness is a false inclination towards materialistic progress and status. The narrator and his family fall behind the peers in social status but they want to be equal to them when his own status gives him many questions on his perception. Thus, the vent of wealth leaves many doubts on the American dream in the minds of the Americans. Thus the present notion of American dream can be said "The gap between the excesses of the wealthy and the state of affairs for the middle class is causing Americans to reconsider their chances for realizing the American Dream” (Ellis 15).

Another linear narrative that runs through the novel is hedonistic human consumerism which depicts that narrator's painlessness in seeking pleasure and by planting SGs in his yard by promoting his status to other peers is a fine example. Humans are used and consumed as goods in his yard. Eva the moral consciousness of the story questions his false hedonism using humans as decoration Pam says:

"Me: Oh, sweetie.

Pam: Let's go look. Let's see do they look sad.

(Do not look sad. Are in fact quietly chatting in moonlight.)" (135).

In fact, we can discern that SGs act opposite to the narrator's hedonistic perspective. They are all altruistic in saving or bringing their families up above the poverty line. SGs have placed their family needs above their needs by sacrificing themselves to the cruel world.

The lives of SGs are horrific as they struggle a lot to provide for the family unlike the 
narrator who struggles to keep up family status by having the SGs hurt and enduring a terrible pain upon them. Narrator tries to convince his daughter of SGs regarding their optimistic side. It is evident in the lines of narrator saying, "Very moving piece on NPR re Bangladeshi SG sending money home: hence her parents able to build small shack. (Note to self: Find online, download, play for Eva. First fix computer. Computer super slow. Possibly delete “Circus Loser"? Acrobats run all jerky, due to low memory + elephants do not hop = no fun.)" (119-120).

The themes that run through this story are quite disturbing to the reader because Saunders doesn't justify the story because it's a perspective of realism. Class conflict in America is highly stressed throughout the story which is modern example of dystopia where middle class fantasizes about owning comforts and luxuries. He also made a comment on system of slavery which took a new turn in owning human like that of objects or commodities. He asks the future reader to understand his America which is under the clutches of false belief in American dream and where uncertainty still persists.

The Semplica-Girl Diaries is actually a dream based story which occurred to Saunders in 1998. The dream was later turned into story bringing the moral myopia of the wealthy who doesn't regret in imploring hard labour on third world immigrants who migrate for the menial jobs. Saunders postulates the idea of SGs in the real life SGs in interview with Debora Treisman saying:

“Then, in 2003, I got sent to Dubai for a writing assignment, and it was like being surrounded by real-life SGs. The whole city was built and run by people who were contracted to be away from home for years at a time, were very low-paid, and were housed in horrific conditions (or, at least, the most poorly paid laborers were). I went into that non-fiction assignment imagining I'd write that story - the story of the rich crapping down on the poor in the name of luxury - and I sort of did, but, once there, also found that (1) yes, this was true, 
and yet (2) there was another side to it, namely that a lot of the workers were wildly happy to be there, because, even given the hardships, they (and their families, to whom they were often sending their entire salaries) were far better off than they had been back home."

It's quite discernible that the real life SGs are the immigrants who leave their families in earning and contributing them financially. The story is a realia to keep every reader to keep open the hearts and eyes to watch the world and its deplorable conditions towards have-nots. 


\section{Works Cited}

Adams, James Truslow. The Epic of America. Transaction Publishers, 2012.

“Christian Hedonism.” Wikipedia, Wikimedia Foundation, 28 Jan. 2021, en.wikipedia.org/wiki/Christian_hedonism.

Ellis, Denise. "Is Too Much Ever Enough? The Economic Crisis, Greed and the Occupy Wall Street Movement.” Journal of Social Work Values and Ethics, vol. 10, no.1, 2013, pp. $13-31$.

Migone, A. (2007). Hedonistic Consumerism: Patterns of Consumption in Contemporary Capitalism. Review of Radical Political Economics, 39(2), 173-200. doi:10.1177/0486613407302482

Philosophy. "Hedonism." Philosophy Terms, 25 Oct. 2018, philosophyterms.com/hedonism/. Rousseau, J.-J., Cress, D. A., \& Miller, J. Discourse on the origin of inequality. Hackett Publishing Company, 1992.

Saunders, George. "The Semplica Girl Diaries.” Tenth of December. The New Yorker, 2012. Treisman, Deborah. “This Week in Fiction: George Saunders.” The New Yorker, 19 June 2017, www.newyorker.com/books/pageturner/this-week-in-fiction-george-saunders-2. www.montclair.edu/writing-studies/wp-content/uploads/sites/35/2019/06/106_ImplausibleAmerican-Dream_Essay-Iroldi.pdf. 